\title{
CRITICAL EVENT PREPAREDNESS AND RESPONSE: KEYNOTE ADDRESS TO THE 2006 SLOAN RESEARCH WORKSHOP BY JON LINKS
}

\author{
Janet C. Moore \\ The Sloan Consortium
}

\begin{abstract}
At the intersection of online education and preparedness, Johns Hopkins University's (JHU) Center for Public Health Preparedness provides all-hazards preparedness and response training for public health and public safety professionals. This report comes from Jonathan Links' keynote address to the Sloan Summer Research Workshop in Baltimore, Maryland in August 2006.
\end{abstract}

\section{KEYWORDS}

Critical Incidents, Continuity of Operations, Preparedness, Training, Online Education

\section{INTRODUCTION}

In 2000, the Center for Disease Control and Prevention (CDC) developed a national network of Centers for Public Health Preparedness (CPHP) [1]:

...to strengthen terrorism and emergency preparedness by linking academic expertise to state and local health agency needs. The program has grown to become an important national resource for the development, delivery, and evaluation of preparedness education. Within the CPHP program, colleges and universities provide preparedness education to public health workers, healthcare providers, students, and others. Currently, 52 CPHPs are established in universities within schools and colleges of public health, medicine, nursing, veterinary medicine, pharmacy, biological sciences, in a community college, and in several university-based medical and health science centers. CPHPs work in close collaboration with state and local health agencies to develop, deliver, and evaluate preparedness education based on community need. [1]

Funded by CDC and led by Jonathan Links [2], the Johns Hopkins University-Center for Public Health Preparedness (JH-CPHP) [3] provides training and education to public health and public safety personnel at the state and local levels, as well as in community-based organizations and other entities charged with carrying out CDC programs and the control and prevention of bioterrorism and infectious disease through all other types of hazards and emergencies (natural, accidental, intentional).

At Hopkins, the JH-CPHP's activities are complemented by the Johns Hopkins' Office of Critical Event Preparedness and Response (CEPAR). CEPAR [4] is the command center-and clearinghouse-for enterprise-wide (throughout Hopkins) planning for and reaction to a catastrophe, particularly involving bioterrorism or nuclear or chemical attack. CEPAR's objectives are:

1. To create, develop and implement a model infrastructure for effective JH enterprise-wide planning and preparedness for critical events requiring a medical/public health disaster response.

2. To develop a model medical/public health disaster response plan integrated with local, regional, 
military and other federal assets.

3. To serve as a model medical/public health disaster planning and response system adaptable to other major metropolitan areas nationally and worldwide. [4]

Thus, JH-CPHP is outward-looking, and JH-CEPAR is inward-looking.

JH-CPHP staff [5] includes a coordinator, trainers, mental health expert, instructional designer, and faculty from the Center for Teaching and Learning with Technology, Environmental Health Sciences, Health Policy \& Management, Interdepartmental Program in Applied Public Health, International Health, the Johns Hopkins Center for Communication Programs, Psychiatry and Behavior Sciences, and other faculty in the School of Public Health and School of Medicine.

\section{ACTIVITIES AND SERVICES}

JH-CPHP develops interactive learning activities in a broad range of preparedness-related fields, including radiation and dirty bombs, occupational health, food and water security, mental health, and cultural competence, including:

- Face-to-face and online training events

- Seminars and conferences

- Certificate programs

- Academic coursework

- Ongoing resources: CD-ROMs, reference books and resource library materials [3]

- One of the Center's “premiere” products is its Road Map to Preparedness.

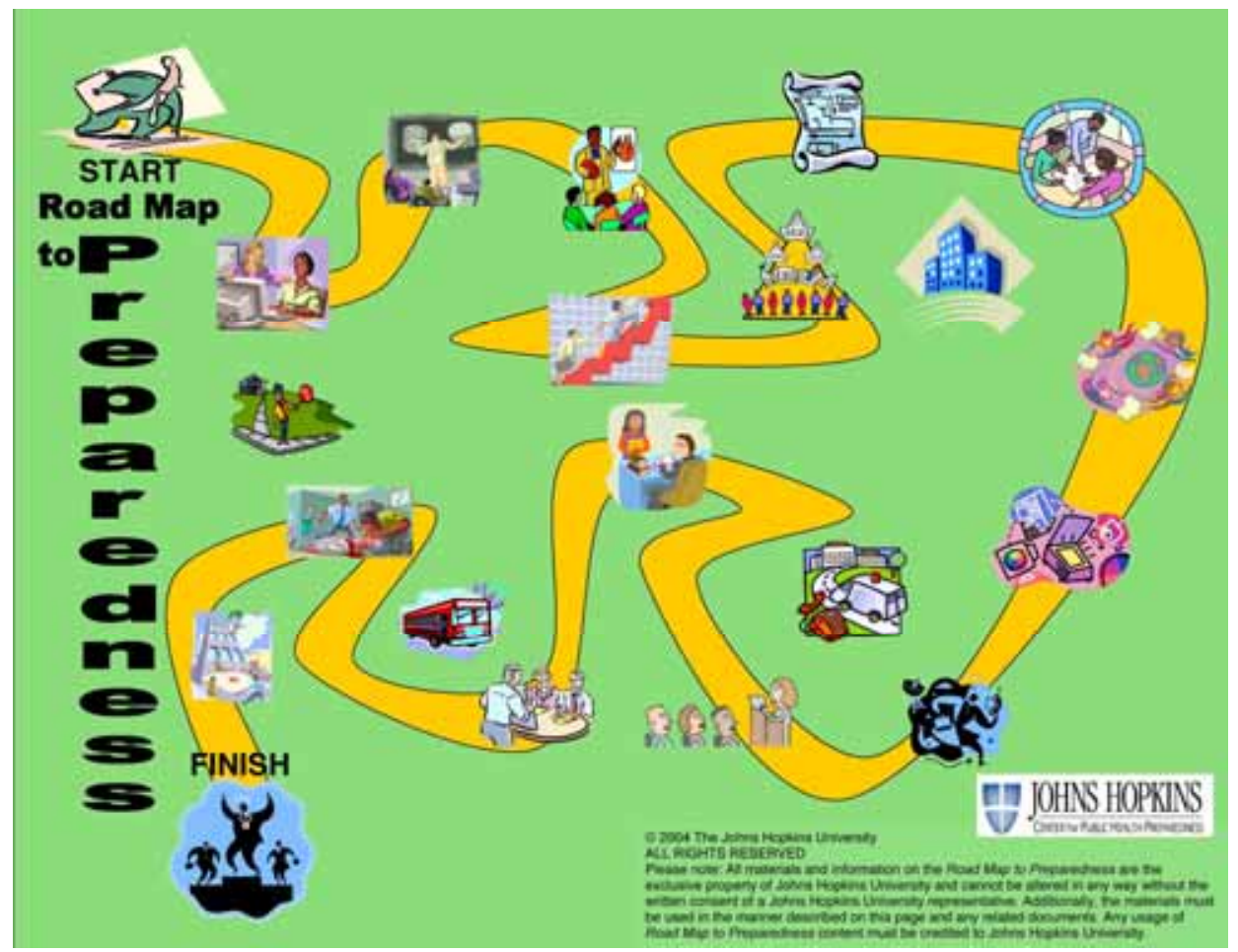

Figure 1. Roadmap to Preparedness 
The Road Map depicts a training program based on CDC preparedness competencies for preparing public health personnel for emergencies. JH-CPHP designed a manual and materials for trainers who teach the Road Map to Preparedness training program to all remaining employees in their own health departments:

The Road Map's goal is to provide a basic training curriculum, applicable to all health department employees, to help them achieve the competencies outlined in the CDC/Columbia University Bioterrorism \& Emergency Readiness: Competencies for All Public Health Workers.[6] (The Center also provides learning objectives [7] that each participant will be expected to achieve.) Because the work of a busy public health department must continue despite the need for this additional training, the program consists of a combination of agency-led activities and self-study activities. Also, because employees are asked to accomplish this training program in addition to their regular duties, it was designed to be fun and game-like. [8]

A free online repository provides learning opportunities with courses and training activities, tools, and educational programs offered through the entire Center for Public Health Preparedness network at the Public Health Preparedness Resource Center [9] maintained by the Association of Schools of Public Health. Terrorism and emergency response training and educational resources developed by the CDCfunded Centers for Public Health Preparedness "address a wide-array of public health and emergency response topic areas and are presented in various formats including CD-ROM, web cast, exercise/drill/tabletop manuals, comprehensive course outlines and much more. This information is intended for public health professionals and other community partners both in the field and in the classroom” [7].

Web modules from JH-CPHP are available on topics including:

- Agriculture, Food, and Water

- Chemical, Biological, Radiological, Nuclear Terror

- Infectious Disease and Vaccines

- Legal Issues

- Mental Health Preparedness

- General Public Health Preparedness

Short courses include:

- Public Health Response Team Institute

- Emerging Infectious Respiratory Diseases

- Dirty Bombs Preparedness \& Response

- Psychological Aspects of Terrorist Events

- Agricultural Security \& Public Health

- Epidemic Intelligence Service Conference

- Disaster Mental Health

- Corporate Emergency Preparedness 
Critical Event Preparedness and Response:

Keynote Address to the 2006 Sloan Research Workshop by Jon Links

JHCPHP achievements are shown in Tables 1 and 2:

\begin{tabular}{|c|c|c|}
\hline Activity & Promised & Delivered \\
\hline $\mathrm{R} 2 \mathrm{P}$ & 3000 (10 dept's) & 3923 (10 dept's) \\
\hline Web modules & $\begin{array}{c}1100 \text { ( } 12 \text { old }+10 \\
\text { new modules) }\end{array}$ & $\begin{array}{c}1582 \text { (12 old }+15 \\
\text { new modules) }\end{array}$ \\
\hline Short courses & $\begin{array}{c}600 \text { (6 courses; } 9 \\
\text { days) }\end{array}$ & $\begin{array}{c}881 \text { (8 courses; } \\
10 \text { days) }\end{array}$ \\
\hline Prep Cert & 10 & 7 \\
\hline MPH Prep Conc & 10 & 8 \\
\hline
\end{tabular}

Table 1. Year 1 Reach

\begin{tabular}{|c|c|c|}
\hline \multicolumn{2}{|c|}{ Promised } & $\begin{array}{c}\text { Estimated } \\
\text { (as of Aug 2006) }\end{array}$ \\
\hline Activity & 850 (7 dept's) & 3081 \\
\hline R2P & 2000 (52 modules) & 3500 \\
\hline Web modules & 850 (6 courses) & 1619 \\
\hline Short courses & 7 & 3 \\
\hline Prep Cert & 8 & 8 \\
\hline MPH Prep Conc & 500 (3 series) & 520 \\
\hline Training Series & 400 & 780 \\
\hline NIMS Training & \multicolumn{2}{|c}{} \\
\hline
\end{tabular}

Table 2. Year 2 Reach

In addition, partners have requested training in:

- Basic Public Health/Surveillance

- All-hazards/ Chemical, Biological, Radiological/Nuclear, and Explosive (CBRNE) Incidents

- National Incident Management System (NIMS)

- Emergency Response Plans (developing, understanding, and using)

- Mental Health

- Legal/Ethical Issues

- Personal Protective Equipment (PPE)

- Drills and Exercises 


\section{TRAINING ISSUES}

\section{A. Barriers to Training}

Barriers to training include the release of staff from regular duties to attend training during business hours and the costs associated with training and temporary staff replacements. Attendants may perceive that the training is not relevant to their duties, or they may perceive that their role in an emergency is not important. Without training that inculcates responsibility, response to incidents is subject to a range of perceptions:

- Perception of existing knowledge about public health impact of pandemic influenza

- Confidence in personal safety

- Family preparation

- Health Department's perceived ability to provide timely information

- Perception of the capacity to effectively communicate risk

- Familiarity with one's role-specific response requirements

- Perception of the importance of one's role in the agency's overall response

- Perceived importance of preparedness training and education [10]

Trainers must take into account that people may not believe threats are real. Figure 2 shows that "preventive health behavior is influenced by five factors: (a) perceived barriers to performing the recommended response; (b) perceived benefits of performing the recommended response; (c) perceived susceptibility to a health threat; (d) perceived severity of a health threat; and (e) cues to action” [11].

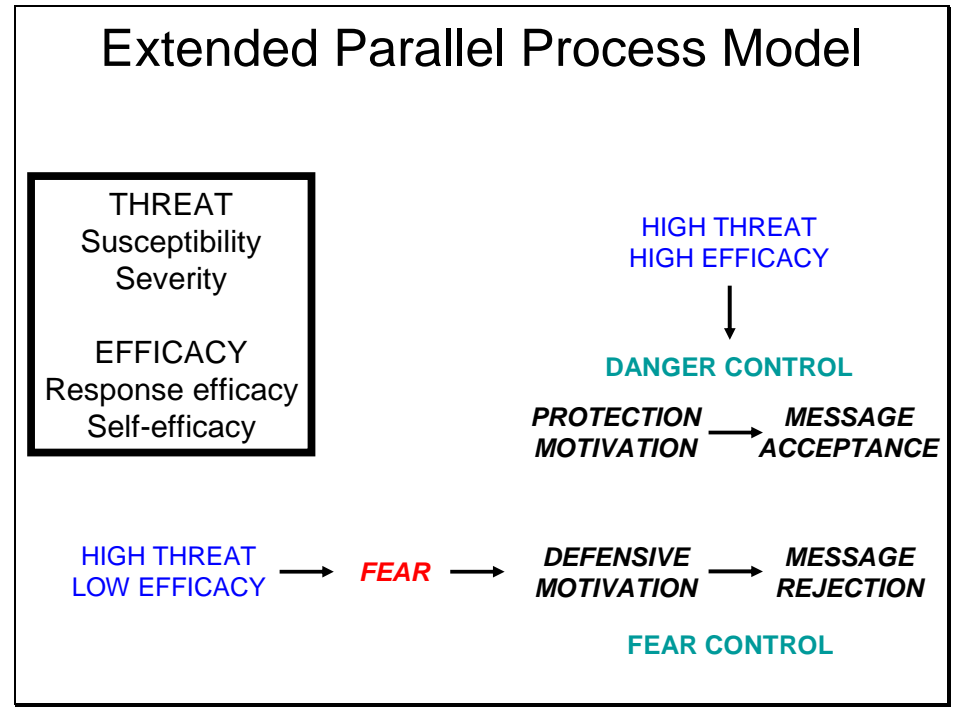

Figure 2. Extended Parallel Process Model

To address these perceptions, it is necessary to change the traditional approach to learning, focusing not just on knowledge, but instead seeking to transform attitudes, beliefs, and behaviors, as illustrated in Figure 3. 


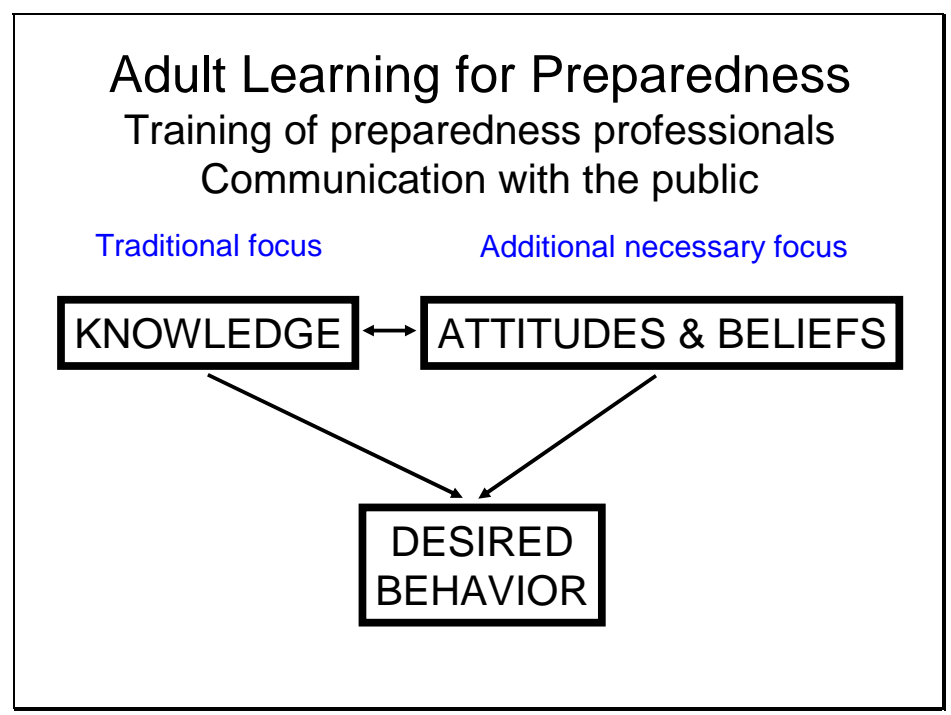

Figure 3. Focus for Preparedness Learning

\section{B. Customization Preferred}

Although a great deal of online training is available [12], a barrier may be that people may not take online learning as seriously as they take in-person learning.

JHCPHP finds that certain groups prefer customization to one-size-fits-all approaches. Thus, a typical training day might consist of morning table talk, followed in the afternoon with didactic presentations based on morning table talk. Because workers in public health and public safety have different cultures, languages and affects, customization helps to bridge the distance among groups.

\section{Assessment}

JHCPHP administers multiple choice exam administered pre and post training, and evaluates real time audience understanding with response system that uses individual remotes tied to participants' identity. Some example results show improvement:

- $\quad$ Roadmap to Preparedness: $47 \%-77 \%$

- Dirty Bomb Table-Top: 57\%-73\%

However, the big challenge is how to assess longer term outcomes after 6 months or more, and how to measure real changes in practice and performance so that readiness is part of everyday awareness.

\section{Format}

Training can occur in a variety of formats. JH-CPHP reports relative interest in the following formats:

Short courses

Courses that offer CE credit

On-site training

Certificate programs

Master degree credits 48\% high interest; 35\% moderate interest 55\% high interest; 21\% moderate interest $56 \%$ high interest; $31 \%$ moderate interest $40 \%$ high interest; $26 \%$ moderate interest $34 \%$ no interest; $21 \%$ low interest 


\section{ALL HAZARDS}

A theme of all hazards training is that $98 \%$ of response is the same. However, each kind of event occurs in stages that are also known as triggering events. The figure below, for example, shows the plumeshaped dispersal effects of a dirty bomb detonated at the Baltimore harbor, suggesting a range of health effects and priorities for responders. Simulations such as those that produced this figure are useful in running table-top exercises.

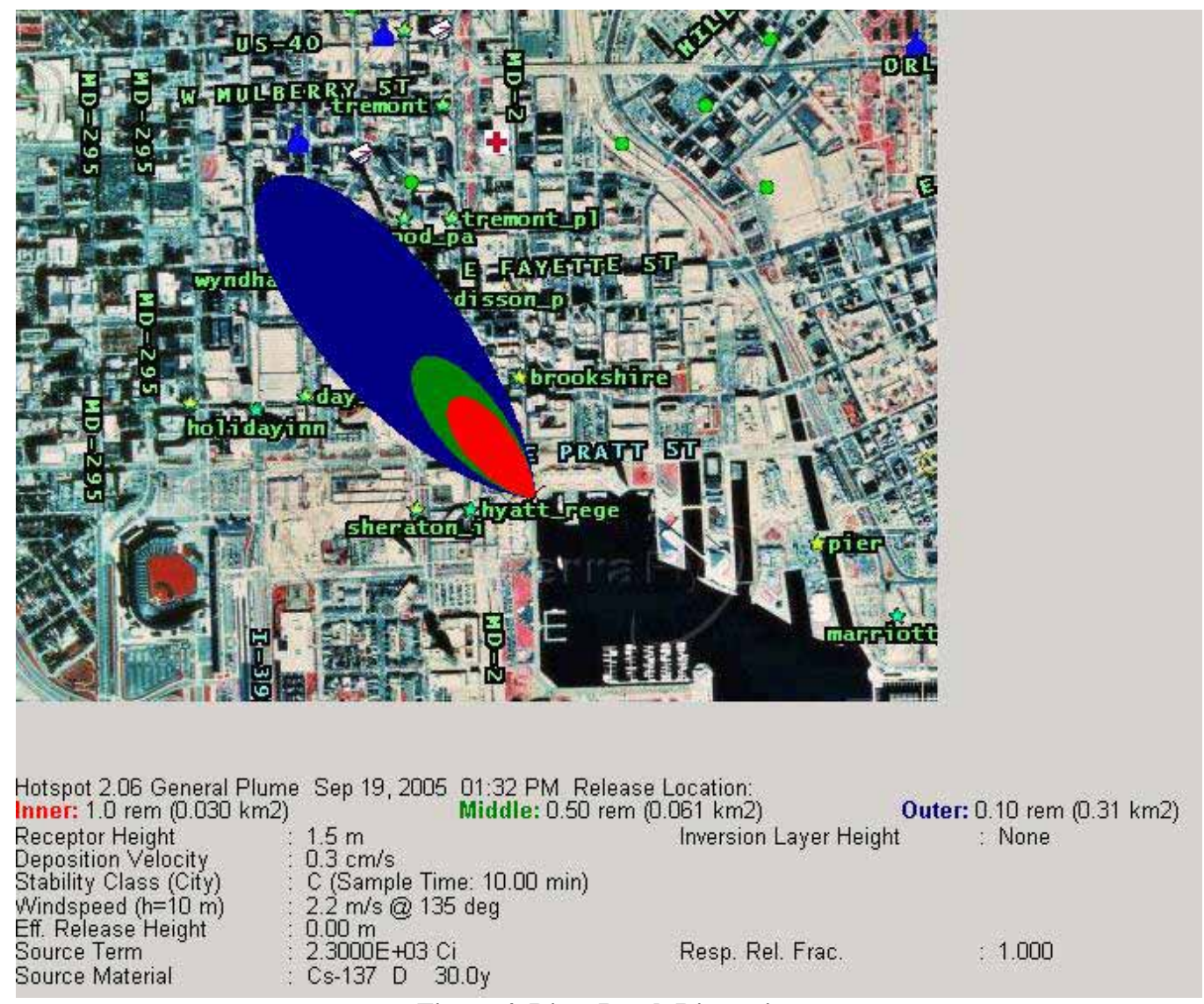

Figure 4. Dirty Bomb Dispersion

Triggering events for Avian or Pandemic Influenza are identified in 6 phases according to the World Health Organization:

\begin{tabular}{|c|c|c|}
\hline \multirow{2}{*}{$\begin{array}{l}\text { Inter-pandemic phase } \\
\text { New virus in animals, no human } \\
\text { cases }\end{array}$} & Low risk of human cases & 1 \\
\hline & Higher risk of human cases & 2 \\
\hline \multirow{3}{*}{ New virus causes human cases } & $\begin{array}{l}\text { No or very limited human-to-human } \\
\text { transmission }\end{array}$ & 3 \\
\hline & $\begin{array}{l}\text { Evidence of increased human-to-human } \\
\text { transmission }\end{array}$ & 4 \\
\hline & $\begin{array}{c}\text { Evidence of significant human-to-human } \\
\text { transmission }\end{array}$ & 5 \\
\hline Pandemic & $\begin{array}{l}\text { Efficient and sustained human-to-human } \\
\text { transmission }\end{array}$ & 6 \\
\hline
\end{tabular}

Figure 5. WHO: 6 Phases of Pandemic, October 2006 [13] 


\section{CONTINUITY OF OPERATIONS PLANS (COOPS)}

Academic continuity of operations plans (COOPS) have traditionally focused on continuity of business (see [14] for example). However, with the advent of online education, it is now possible to plan for continuity of educational and research activities before, during, and after the emergency.

Figure 4 depicts Johns Hopkins' School of Public Health leadership and authority incident command structure in the context of pandemic flu preparedness and response:

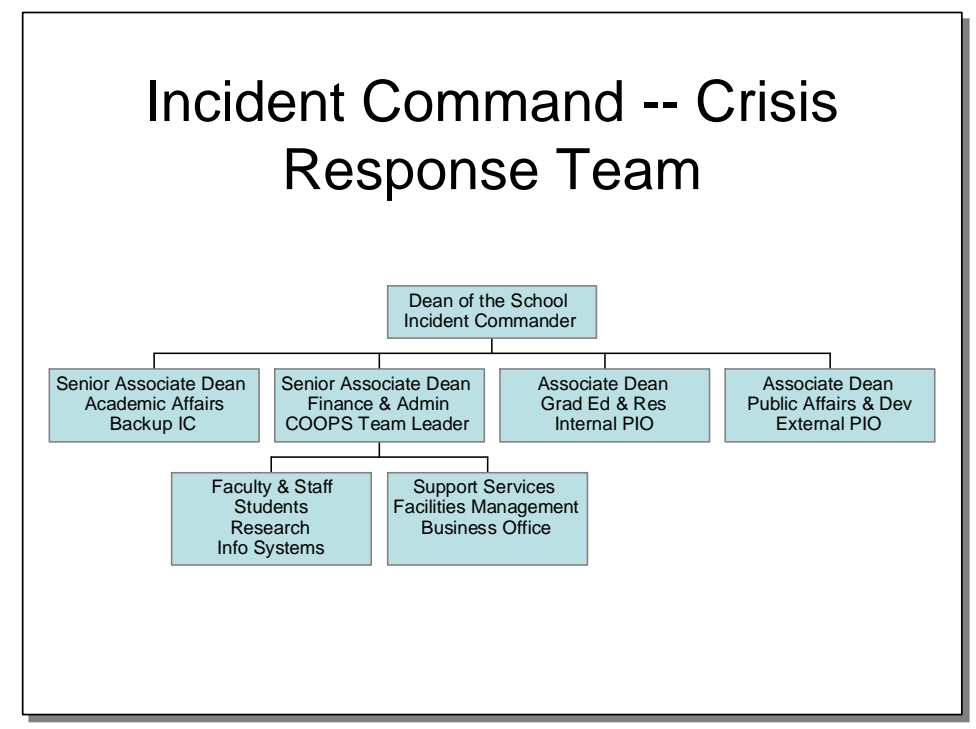

Figure 6. Incident Command Structure

JHU is developing plans to enable fully online delivery of courses and establishing policies for class and course cancellation and for excused and unexcused absences. It is planning for freezers to maintain biological specimens. It is also examining strategies for paying union employees who can work from home and for insuring against disease. Among the biggest concerns is providing for added capacity for servers, networks, and software licenses.

Keeping in mind that people need to remain aware of continuity planning as part of routine operations, JHU prepares all-hazards readiness and ask what triggers actions from one stage to the next. For example, in the event of pandemic when absenteeism is expected to be $40-50 \%$, routine operations emphasize readying alternative communications (website backups, palm held devices, 2-way radios), flu shots, and travel screening; reduced operations would cancel seminars, clubs, and visitors; at the essentials stage, only mission critical personnel will be physically present. In all these contingencies, JHU emphasizes that preparedness is not just planning to "do," but actually "doing."

\section{ADDITIONAL READINGS: PEER-REVIEWED ARTICLES}

1. Barnett, D. J., R. D. Balicer, D. Blodgett, A. L. Fews, C. L. Parker and J. M. Links. The Application of the Haddon Matrix to Public Health Readiness and Response Planning. Environmental Health Perspectives 113(5): 561-566, May 2005.

2. Barnett, D. J., R. D. Balicer, D. W. Blodgett, G. S. Everly, S. B. Omer, C. L. Parker and J. M. Links. Applying Risk Perception Theory to Public Health Workforce Preparedness Training. Journal of Public Health Management Practice 11(6 Supplement): S33-S37, November 2005. 
3. Barnett, D. J., R. D. Balicer, D. R. Lucey, G. S. Everly, S. B. Omer, M. C. Steinhoff and I. Grotto. A Systematic Analytic Approach to Pandemic Influenza Preparedness Planning. PLoS Medicine 2(12): e359, December 2005.

4. Barnett D. J., G. S. Everly, C. L. Parker and J. M. Links. Applying Educational Gaming to Public Health Workforce Emergency Preparedness. American Journal of Preventive Medicine 28(4): 390395, May 2005.

5. Covich J, C. Parker and V. White. The Practice Community Meets the Ivory Tower: A Partnership to Improve Public Health Preparedness. Public Health Reports 120(Suppl.1): 84-90, 2005.

6. Parker C. L., D. J. Barnett, A. L. Fews, D. Blodgett and J. M. Links. The Road Map to Preparedness: A Competency-Based Approach to All-Hazards Emergency Readiness Training for the Public Health Workforce. Public Health Reports, 120(5): 504-514, September/October 2005.

\section{REFERENCES}

1. Centers for Public Health Preparedness. http://www.bt.cdc.gov/training/cphp/index.asp.

2. Jonathan Links. http://faculty.jhsph.edu/?F=Jonathan\&L=Links.

3. Center for Public Health Preparedness. Johns Hopkins University. http://www.jhsph.edu/preparedness/index.ht ml.

4. Critical Event Preparedness and Response. http://www.hopkins-cepar.org/index.html.

5. Key Personnel and Staff. http://www.jhsph.edu/preparedness/about/faculty_staff.html.

6. Competencies for All Public Health Workers. CDC/Columbia University Bioterrorism and Emergency Readiness. http://www.cumc.columbia.edu/dept/nursing/institutes-centers/chphsr /btcomps.pdf.

7. Road Map Learning Objectives. http://www.jhsph.edu/preparedness/Materials/Road_map_learning objectives.pdf.

8. Road Map to Preparedness. http://www.jhsph.edu/preparedness/training/road map.html.

9. Public Health Preparedness Resource Center. http://asph.org/acphp/phprc.cfm.

10. Barnett D. J., R. D. Balicer, D. Blodgett, A. L. Fews, C. L. Parker and J. M. Links. The Application of the Haddon Matrix to Public Health Readiness and Response Planning. Environmental Health Perspectives 113(5): 561-566, May 2005.

11. Witte, K. Theory-Based Interventions and Evaluations of Outreach Efforts. http://nnlm.gov/archive/pnr/eval/witte.html.

12. Emergency Management and Command. National Incident Management System. http://www.nimsonline.com/nims_training/index.htm.

13. Epidemic and Pandemic Alert and Response (EPR). World Health Organization. http://www.who.int/csr/disease/avian_influenza/phase/en/index.html.

14. Johns Hopkins Medical Institutions JHMCIS/IT@JH Business Continuity Plan. http://it.jhu.edu/etso/dr/bcplan.html. 